\title{
SEROPREVALENCE OF TORCH ANTIBODY IN PREGNANT WOMEN
}

\author{
Nabi $\mathrm{SN}^{1}$, Wasey $\mathrm{AFSA}^{2}$, Haider $\mathrm{KMTS}^{3}$, Khan $\mathrm{AA}^{4}$, Hoque $\mathrm{MM}^{5}$
}

\begin{abstract}
Introduction: Infection by Toxoplasma gondii, Rubella, Cytomegalovirus (CMV), Herpes simplex virus-1 (HSV-I) and Herpes simplex virus-2 (HSV-2) (TORCH) group of organisms in pregnancy are the leading causes of congenital anomalies throughout the world. Most of the TORCH infections cause mild maternal morbidity but have serious foetal consequences and treatment of maternal infection frequently has no impact on foetal outcome. Therefore, recognition of maternal disease and foetal monitoring once the disease is recognized is important.
\end{abstract}

Objectives: This cross sectional descriptive study was carried out to determine the seroprevalence of TORCH antibodies in pregnant women.

Method: Single blood sample was taken from 111 pregnant women, 46 from 1 st trimester, 35 from the 2nd trimester and 30 from the 3rd trimester of pregnancy. Blood samples were collected from out patient departments of Combined Military Hospital (CMH) Dhaka and Armed Forces Institute of Pathology (AFIP) Dhaka Cantonment during the period of October 2006 to July 2007. Blood samples were kept at room temperature to allow clot formation and sera were separated by centrifugation and stored in $.2 \mathrm{ml}$ aliquot at $-20^{0} \mathrm{c}$ till testing. All the samples were tested by Enzyme Linked Immunosorbent Assay (ELISA) method for TORCH specific immunoglobulin $\mathrm{G}(1 \mathrm{gG})$ and immunoglobulin $M(1 \mathrm{gM})$ classes of antibodies.

Result: The over all rate of seropositivity for TORCH specific antibodies found in this study were as follows: $\mathbf{2 4 . 3 2} \%$ for Toxoplasma, $\mathbf{8 7 . 3 8 \%}$ for Rubella, $\mathbf{9 6 . 3 9 \%}$ for CMV, $\mathbf{9 0 . 0 9 \%}$ for HSV-1 and $11.71 \%$ for HSV-2. The IgG antibodies against Toxoplasma, Rubella, CMV, HSV-1 and HSV-2 were found positive in $23.42 \%, 81.08 \%, 95.49 \%, 87.39 \%$ and $9.91 \%$ cases respectively and the IgM antibodies were found positive in $0.90 \%, 6.30 \%, 0.90 \%, 2.70 \%$ and $1.80 \%$ for Toxoplasma, Rubella, CMV, $\mathrm{HSV}-1$ and $\mathrm{HSV}-2$ respectively.

Conclusion: The finding of this study reveals the seroprevalence of TORCH infections in the country. This study will help to create awareness amongst patients and obstetricians about TORCH infections in pregnancy and their consequences and to take the preventive and other appropriate measures against them. Keywords: TORCH antibody, seroprevalence, pregnant women

\section{Introduction}

TORCH, which includes Toxoplasmosis, Rubella, Cytomegalovirus (CMV), and Herpes simplex infections are some of the most common infections associated with congenital anomalies. Most of the TORCH infections cause mild maternal morbidity but have serious foetal consequences and treatment of maternal infection frequently has no impact on foetal outcome ${ }^{1}$. Maternal TORCH infection during pregnancy is a threat to pregnancy because they can be transmitted to the foetus while in the womb ${ }^{2}$. Therefore, recognition of maternal disease and foetal monitoring once the disease is recognized is important for all clinicians ${ }^{3}$.

The consequences of these infections on foetus

1. Lt Col Syed Nurun Nabi MBBS, MCPS, DCP, FCPS, Graded Specialist in Pathology, CMH Comilla Cantonment; 2. Brig Gen A F S A Wasey MBBS, DMM, FCPS, Professor and Head, Department of Pathology, AFMC; 3. Brig Gen K M T S Haider, MBBS, MD, Professor and Head, Department of Microbiology, AFMC; 4. Col Arif Ahmed Khan, MBBS, MCPS, FCPS, Classified Specialist in Pathology, CMH Comilla Cantonment; 5. Lt Col Md Monirul Hoque, MBBS, MCPS, DCP, FCPS, Graded Specialist in Pathology, Armed Forces Institute of Pathology. 
depend upon the type and virulence of the infecting agent and the stage of pregnancy. If a mother is exposed to these infections during the first five months of pregnancy, serious foetal complication may occur. These include miscarriage, small for gestational age, prematurity, failure to thrive, congenital heart disease, cataract, chorioretinitis, microophthalmia, blindness, microcephaly, mental retardation, hearing impairment etc. ${ }^{3,4}$.

The social and reproductive maladjustment because of repeated pregnancy wastages, cost of treatment and morbidity caused to infant make the TORCH group of infections a major cause of concern. The prevalence of these infections varies from one geographical area to another. Many sensitive and specific tests are available for serological diagnosis of TORCH complex. Enzyme Linked Immunosorbent Assay (ELISA) for immunoglobulin $\mathrm{M}(\operatorname{IgM})$ and immunoglobulin $\mathrm{G}$ ( $\mathrm{IgG}$ ) antibodies against these infections is highly sensitive and specific ${ }^{5,6}$.

This cross sectional study was carried out to determine the seroprevalence of TROCH specific antibodies in pregnant women, in order to asses their immune status and their vulnerability to Toxoplasma, Rubella, Cytomegalovirus and Herpes simplex virus infections.

\section{Materials and Methods}

The study was carried out in the Department of Immunology and Virology at Armed Forces Institute of Pathology (AFIP) Dhaka Cantonment during the period of October 2006 to July 2007. A total of 111 pregnant women were investigated. Among them 46 were in the first trimester, 35 in the Table -I: Seropositivity distribution of TORCH specific antibodies in the study population $(\mathrm{n}=111)$

\begin{tabular}{|l|l|l|l|l|l|}
\hline Seropositivity & $\begin{array}{l}\text { Toxoplasma } \\
\text { No. }(\%)\end{array}$ & Rubella f (\%) & $\begin{array}{l}\text { CMV No. } \\
(\mathbf{\%})\end{array}$ & $\begin{array}{l}\text { HSV-1 No. } \\
(\mathbf{\%})\end{array}$ & $\begin{array}{l}\text { HSV-2 No. } \\
(\mathbf{\%})\end{array}$ \\
\hline Seropositive & $27(24.32)$ & $97(87.38)$ & $107(96.39)$ & $100(90.09)$ & $13(11.71)$ \\
\hline Seronegative & $84(75.68)$ & $14(12.62)$ & $04(03.61)$ & $11(09.91)$ & $98(88.29)$ \\
\hline
\end{tabular}

second trimester and 30 were in the third trimester of pregnancy. The study cases were randomly selected from those who reported to AFIP, different family outpatient departments and indoor cases of Combined Military Hospital $(\mathrm{CMH})$ Dhaka. The cases were referred patients from different clinics and hospitals of Dhaka city.

About 4-6 ml of blood was collected aseptically by venipuncture in a sterile dry test tube from each pregnant woman. The blood samples were kept at room temperature to allow clot formation and sera were separated by centrifugation and stored in $0.2 \mathrm{ml}$ aliquot at $-20{ }^{\circ} \mathrm{C}$ till testing. All the sera were tested for TORCH specific IgG and IgM classes of antibodies by Enzyme Linked Immunosorbent Assay (ELISA) method. The tests were performed with commercially available kits and the manufacturer's instructions were followed strictly. The patients were interviewed using a predestined structured questionnaire to collect data and other relevant findings. Finally data were compiled and analyzed manually and then presented in tabular forms.

\section{Results}

Out of 111 pregnant women tested for TORCH specific antibodies, 27(24.32\%) were seropositive for Toxoplasma gondii specific antibody, 97(87.38 $\%$ were positive for Rubella antibody, 107(96.39\%) were positive for CMV antibody, $100(90.09 \%)$ were positive for HSV-1 antibody and $13(11.71 \%)$ were positive for HSV-2 antibody (Table-I). Distribution of specific IgG and IgM antibodies of TORCH agents amongst pregnant women has been shown in table-II. Distribution of pregnant women as per their age group and duration of pregnancy have been shown in table-III. The age of the youngest one was 17 years and the oldest one was 37 years.
Table -II: Distribution of TORCH specific $1 \mathrm{gG}$ and $1 \mathrm{gM}$ antibodies $(\mathrm{n}=111)$

\begin{tabular}{|l|l|l|l|l|l|}
\hline $\begin{array}{l}\text { Antibody } \\
\text { Type }\end{array}$ & $\begin{array}{l}\text { Toxoplasma } \\
\text { No. (\%) }\end{array}$ & $\begin{array}{l}\text { Rubella } \\
\text { No. (\%) }\end{array}$ & $\begin{array}{l}\text { CMV No. } \\
\text { (\%) }\end{array}$ & $\begin{array}{l}\text { HSV-1 } \\
\text { No. (\%) }\end{array}$ & $\begin{array}{l}\text { HSV-2 } \\
\text { No. (\%) }\end{array}$ \\
\hline IgG & $26(23.42)$ & $90(81.08)$ & $106(95.49)$ & $97(87.39)$ & $11(9.91)$ \\
\hline IgM & $01(00.90)$ & $07(06.30)$ & $01(00.90)$ & $03(02.70)$ & $02(1.80)$ \\
\hline
\end{tabular}


Table -III: Distribution of pregnant women as per the age group and trimester of pregnancy $(\mathrm{n}=111)$.

\begin{tabular}{|l|l|l|l|l|}
\hline Age group & $\begin{array}{l}\text { 1st Trimester } \\
\text { No. }(\%)\end{array}$ & $\begin{array}{l}\text { 2nd Trimester } \\
\text { No. (\%) }\end{array}$ & $\begin{array}{l}\text { 3rd Trimester } \\
\text { No. }(\%)\end{array}$ & $\begin{array}{l}\text { Total No. } \\
(\%)\end{array}$ \\
\hline $16-20$ & $06(05.40)$ & $03(2.70)$ & $6(5.40)$ & $15(13.52)$ \\
\hline $21-25$ & $20(18.02)$ & $10(9.01)$ & $7(6.31)$ & $37(33.33)$ \\
\hline $26-30$ & $12(10.81)$ & $11(9.92)$ & $5(4.51)$ & $28(25.22)$ \\
\hline $31-35$ & $06(05.40)$ & $07(6.30)$ & $9(8.11)$ & $22(19.82)$ \\
\hline $36-40$ & $02(01.81)$ & $04(3.60)$ & $3(2.70)$ & $09(08.11)$ \\
\hline Grand total & $46(41.44)$ & $35(31.53)$ & $30(27.03)$ & $111(100)$ \\
\hline
\end{tabular}

When $\operatorname{IgM}$ antibody is present, it invariably suggests acute/recent infection and the presence of IgG antibody suggests past or present active infection ${ }^{3,4,7}$.

In the present study, an attempt was made to assess the seroprevalence of TORCH specific antibodies in pregnant women on the basis of detection of $\operatorname{IgG}$ and/or $\operatorname{IgM}$

Table -IV: Distribution of TORCH specific antibodies amongst women with previous normal pregnancy outcome group and women with bad obstetric history group $(n=99)$

\begin{tabular}{|l|l|l|l|l|l|l|}
\hline $\begin{array}{l}\text { Type of previous } \\
\text { pregnancy out come }\end{array}$ & $\begin{array}{l}\text { Total No. } \\
(\%)\end{array}$ & $\begin{array}{l}\text { Toxoplasma } \\
\text { No. (\%) }\end{array}$ & $\begin{array}{l}\text { Rubella } \\
\text { No. (\%) }\end{array}$ & $\begin{array}{l}\text { CMV No. } \\
(\%)\end{array}$ & $\begin{array}{l}\text { HSV-I No. } \\
(\%)\end{array}$ & HSV-2 No. (\%) \\
\hline $\begin{array}{l}\text { Normal pregnancy } \\
\text { outcome }\end{array}$ & $57(57.57)$ & $13(22.80)$ & $48(84.21)$ & $54(94.73)$ & $49(85.96)$ & $07(12.28)$ \\
\hline Bad obstetric history & $42(42.42)$ & $11(26.19)$ & $39(92.85)$ & $41(97.61)$ & $40(95.23)$ & $05(11.90)$ \\
\hline
\end{tabular}

Relationship between TORCH specific antibodies in women with previous normal pregnancy out come group and women with previous bad obstetric history group have been shown in Table-IV. Out of 111 cases, 12(10.81\%) were primigravida and $99(89.19 \%)$ were multigravida. Among 99 multigravida cases, 57(57.57\%) had history of previous normal pregnancy out come and $42(42.42 \%)$ had previous bad obstetric history. Among the 57 women with previous normal pregnancy outcome, $22.80 \%, 84.21 \%$, $94.73 \%, 85.96 \%$ and $12.28 \%$ cases were seropositive for Toxoplasma, Rubella, CMV, HSV-1 and HSV-2 antibodies respectively and amongst the 42 women with previous bad obstetric history, these rates were $26.19 \%$, $92.85 \%, \quad 97.61 \%, \quad 95.23 \%$ and $11.90 \%$ respectively. The seropositivity rates were slightly higher in women with previous bad obstetric outcome group than the normal pregnancy outcome group but the differences were not statistically significant ( $p>0.05$ ).

\section{Discussion}

Any patient infected with the TORCH group of agents, mainly two types of antibodies are produced against the infecting organisms ${ }^{6}$. These are of immunoglobulin $\mathrm{M}(\mathrm{IgM})$ and immunoglobulin $\mathrm{G}(\mathrm{IgG})$ types. By the way of measuring the antibody in mother's blood, we can identify the type of infection. antibodies. The overall prevalence of seropositivity found in this study were $24.32 \%$ for toxoplasma, $87.38 \%$ for rubella, $96.39 \%$ for CMV, 90.09 for HSV-1 and $11.71 \%$ for HSV-2 (Table-1). In a similar study carried out in Bangladesh by Rowshan A and Mahamuda K in 2001 where the seropositivity for TORCH specific antibodies found were $48 \%$ for toxoplasma, $93 \%$ for rubella, $90 \%$ for CMV, $88 \%$ for HSV. The distribution of $1 \mathrm{gM}$ antibodies in their study were $1 \%$ for toxoplasma, $8 \%$ for rubella, $1 \%$ for CMV and $2 \%$ for $\mathrm{HSV}-1^{2}$. This result well correlates with the present study except the seroprevalence of toxoplasma, which was lower in the present study. Another study in Bangladesh by Arif A, Motiur R, Nizamuddin A et al found the seroprevalence of toxoplasma as $20 \%{ }^{7}$. A study conducted in India by Turbadker D, Mathur M, Rele M showed the seropositivity for toxoplasma, rubella, CMV, HSV- 1 as $52.62 \%, 88.10 \%, 99.47 \%$ and $37.18 \%$ respectively ${ }^{3}$. Another study conducted in India showed seropositivity of toxoplasma as $50.52 \%{ }^{8}$. Studies in Thailand and Hong Kong showed seroprevalence of toxoplasma to be $13.0 \%$ and $9.8 \%$ respectively ${ }^{9,10}$.

In case of rubella infection, $87.38 \%$ seropositivity was found in our study. In a study conducted in Bangladesh by Jubida N, Mondal MEA, and Kawser NA it was found that $94.33 \%$ of pregnant 
women were seropositive for rubella specific IgG antibody and $0.75 \%$ for IgM antibody ${ }^{11}$. In another study carried by Nahar $\mathrm{N}$ in Bangladesh observed that the seroprevalence of rubella specific $1 \mathrm{gG}$ antibody was $69.2 \%{ }^{12}$. Studies conducted in Pakistan and Malaysia showed the seroprevalence of rubella as $94 \%$ and $92.3 \%$ respectively ${ }^{13}$.

The reason for this difference in the immunity in various countries is difficult to explain, however factors such as net birth rate, population density, level of herd immunity, ethnicity etc may play a role ${ }^{14}$.

Seroprevalence of CMV was $96.39 \%$ in the present study. Samad, Dey and Khan found $84 \%$ seropositivity in a study in Bangladesh ${ }^{15}$. Studies from India and Turkey reported CMV seropositivity as $84.5 \%$ and $96.4 \%$ respectively 16,17 . In this study HSV-1 antibody was found in $90.09 \%$ cases and HSV-2 antibody in $11.71 \%$ cases. In USA the seropositivity reported $90 \%$ for HSV-1 and $20-25 \%$ for HSV- ${ }^{18}$ and the IgG antibody seropositivity reported $90.90 \%$ for HSV-1 and $27.10 \%$ for HSV-2 from Saudi Arabia ${ }^{19}$.

\section{Conclusion}

The present study demonstrates a high seroprevalence rate of TORCH specific antibodies in pregnant women in our country. Recognition of these infections will help the clinician to appropriately counsel mothers on preventive measures to avoid these infections and aid in counseling parents on the potential for adverse fetal outcomes when these infections are present. Early diagnosis will help in proper management of the cases. It is therefore recommended that all pregnant women should be routinely screened for TORCH agents at the first antenatal visit and the patient should be managed accordingly. Awareness amongst clinicians and patients about TORCH infections and their consequences should be developed.

\section{References}

1. Stegmann BJ, Carey JC. TORCH Infections. Toxoplasmosis, Other (syphilis, vericella-zoster, parvovirus B19), Rubella, Cytomegalovirus (CMV), and Herpes Infections. Curr Women's Health Rep 2002 Aug ; 2 (4): 253-258.

2. Rawshan $A$, Mahamuda K. TORCH Infection: $A$ real threat to pregnancy. Journal of Bangladesh College of Physicians and surgeons 2001; 19:101-105.

3. Turbadkar D, Mathur M, Rele M. Seroprevalence of TORCH infection in bad obstetric history. Indian J Med Microbiol 2003; 21(2): 108-110.

4. Medical test encyclopedia, Discoveryhealth.com. TORCH screen. [Online] [Access 2004July] Available from URL http:/healthdiscovery.com/encyclopedias/1509.html

5. Rajendra B Surpam et al. Seroprevalence of TORCH infection in bad obstetric history. J Obstet Gynecol India 2006 jan; 56; 41-43.

6. Molhotra V, Bhardwaj Y. Comparison of enzyme linked immunosorbant assay and haemagglutination test in serological diagnosis of toxoplasmosis. J Communicable Dis 1991; 23:154-156.

7. Arif A, Motiur R, Nizamuddin A et al. Seroprevalence of Toxoplasma gondii amongst pregnant women in Bangladesh. Bangladesh Armed Forces Medical Journal 2003; 31: 75-79.

8. Mihal V, Bhatia R, Sigh VK, Sehgral S. Seroprevalence of Toxoplasma in Indian women of child bearing age. India J Patholo- Microbiology 1995; 38 (2): 143-145.

9. Bunag $\mathrm{T}$, Klongkammuankarn $\mathrm{K}$, Impand $\mathrm{P}$, Vorranta P and Nabneam K. Seroepidemiology of toxoplasmosis in rural village, Phayao Province. J Med Assoc Thai 1998; 71: 96-99.

10. Korc, Wong FW, Todd D and Lam KC. Prevalence of toxoplamsa gondii antibodies in the ethnics population of Hong Kong. Royal Soc Trop Med Hyg 1980; 74:351-354.

11. Jubida N, Mondal MEA, and Kawser NA Seroprevalence of rubella antibodies in pregnant women. JAFMC Bangladesh 2011 June; 01;20-21.

12. Nahar N. The Seroepidemiology of rubella in Dhaka, Bangladesh. (Thesis).Dhaka, IPGMR 1984: 66-75.

13. Saleen A, Aslam KH. Prevalence of rubella seropositivity at successive stages of pregnancy. Pak Armed Forces med J 1997; 47 (1): 11-14.

14. Jinda N, Aggarwal A. A pilot seroepidemiological study on cytomegalovirus infection in women of child bearing age. Indian J med microbiology 2003; 23: 34-36.

15. Samad MA, Dey BC, Khan MR. Seroprevalence of Rubella, T. gondii and Cytomegalovirus (CMV) 
among the pregnant mothers attending a Medical Collage Hospital in Bangladesh. Bangladesh Med J 1999; 89(324): 36-39.

16. Shanmugam J, Raveendranath $M$, Nair VR. Seroprevalence of rubella and cytomegalovirus infection in pregnant women from Kerala state. J Indian Assoc Commun Dis 1982; 5(3-4): 58-63.

17. Tamer GS, Dunder D, Caliskan E. Seroprevalence of toxoplasma gondii, rubella and cytomegalovirus among pregnant women in western region of Turkey. J Clin Invest Med 2009; 32(1): 43-47.

18. Caroline M, Rudnic, Grant S. Herpes simplex virus infection, Am Fam physician2002; 65: 1138-1142.

19. Ghazi HO, Telmesani AM, Mahomed MF. TORCH agents in pregnant Saudi women. Med Princ Pract 2002 Oct; 11 (4): 180-182. 